\title{
Deteksi Dini Masalah Psikologis Anak Jalanan pada Orangtua Asuh di Rumah Singgah
}

SURYANTO $^{1}$, IKE HERDIANA ${ }^{1 *}$ \& ACHMAD CHUSAIRI ${ }^{1}$

[1] Departemen Psikologi Kepribadian dan Sosial, Fakultas Psikologi, Universitas Airlangga

\begin{abstract}
ABSTRAK
Tujuan dari penelitian ini adalah melakukan deteksi dini permasalahan anak jalanan yang berada di rumah singgah. Penelitian ini menggunakan pendekatan kualitatif. Partisipan adalah lima pengasuh dari tiga rumah singgah anak jalanan di Surabaya. Metode pengambilan data adalah Focus Group Discussion (FGD). Hasil penelitian menunjukkan; (1) perilaku spesifik anak: mengganggu teman, malas, banyak bermain, memegang alat vital temannya, berkata kotor, motivasi belajar rendah, membangkang, memukul teman, keras kepala, kesulitan belajar; (2) perilaku bermasalah: anak yang mengancam bunuh diri; (3) interaksi anak dengan orangtua asuh: baik, intens, pengasuh terlibat membantu mengatasi masalah anak; (4) permasalahan emosional anak: mudah marah, tersinggung, kurang terbuka, membentak teman dan pendamping, memukul teman, emosional saat bicara, cemas, marah, perasaan bersalah dan sedih; (5) faktor penyebab anak asuh bermasalah: pergaulan, lingkungan sekolah, kurangnya afeksi orangtua, kurangnya minat belajar, perilaku kekerasan yang diterima anak dari orangtua kandung, kemiskinan dan keluarga tidak harmonis.
\end{abstract}

Kata kunci: anakjalanan, deteksi dini, masalah psikologis, orangtua asuh, rumah singgah.

\begin{abstract}
The purpose of this study was to perform early detection of street children psychological problems, who were living in shelters. This study used a qualitative approach. Participants are five foster parents of three street children shelters in Surabaya. The data collection method was Focus Group Discussion (FGD). The results showed (1) the specific behavior of children: teasing, lazy, spending too much time for playing, holding his genitals, cursing, low learning motivation, defiant, aggresive, stubborn, learning difficulties; (2) the problematic behavior: the child who threatens suicide; (3) The interaction of the child with foster parents: good, intense, engaged caregivers to help overcome the problem of children; (4) children emotional problems: irritability, irritable, less open, yelling at friends and foster parents, hitting friends, emotional while speaking, anxiety, anger, guilt and sorrow; (5) factors causing behavioural problems: social, school environment, lack of parental affection, lack of interest in learning, violent behavior from children's biological parents, poverty and intense conflict in the family.
\end{abstract}

Key words: early detection, foster parents, psychological problems, shelter, street children. 
INSAN Jurnal Psikologi dan Kesehatan Mental, 2016, Vol. 1(2), 85-96, doi: 10.20473/JPKM.v1i22016.85-96 Dikirimkan: 24/10/2016 Direvisi: 17/12/2016 Diterima: 20/12/2016 Diterbitkan: 31/12/2016 Editor: Rizqy Amelia Zein

*Alamat korespondensi: Kampus B Universitas Airlangga, Jalan Airlangga 4-6 Surabaya 60286. Surel: ike.herdiana@psikologi.unair.ac.id.

Naskah ini merupakan naskah dengan akses terbuka dibawah ketentuan the Creative Common Attribution License (http://creativecommons.org/licenses/by/4.0), sehingga penggunaan, distribusi, reproduksi dalam media apapun atas artikel ini tidak dibatasi, selama sumber aslinya disitir dengan baik.

\section{P E N D A H U L U A N}

Jumlah anak jalanan mengalami peningkatan yang signifikan dari tahun ke tahun. Berdasarkan data dari Pusat Data dan Informasi Kesejahteraan Sosial Kementerian Sosial jumlah anak jalanan di seluruh Indonesia sebagai Tahun 2006 sebanyak 232.894 anak, tahun 2010 sebanyak 159.230 anak, tahun 2011 sebanyak 67.607 anak, dan tahun 2015 sebanyak 33.400 anak. Data lain dari Kementrian Sosial (Kemensos) juga mencatat, jumlah anak jalanan (anjal) pada tahun 2016 mencapai sekitar 4,1 juta atau meningkat secara drastis dari tahun 2015 (Direktorat Jenderal Rehabilitasi Sosial, 2016).

Berbagai upaya juga sudah dilakukan oleh pemerintah baik di tingkat pusat maupun di daerah untuk menangani masalah anak jalanan ini. Salah satu upaya pemerintah kota Surabaya untuk mengatasi masalah anak jalanan adalah mendorong anak jalanan untuk tidak beraktivitas di jalan dan berupaya menjadikan mereka menjalani hidup normal. Indikator dari hidup normal tersebut salah satunya adalah kembali kepada keluarganya jika ada, maupun mau bersekolah. Proses tersebut membutuhkan proses mulai menjaring anak jalanan dari jalan, menampung mereka sementara, sampai mengedukasi mereka hingga siap dilepaskan ke dalam masyarakat sebagai individu mandiri. Pemerintah Kota Surabaya memiliki dua model penanganan anak jalanan berdasarkan fasilitas yang digunakan yaitu yang ditampung di Lingkungan Pondok Sosial (Liponsos) Keputih di Kecamatan Keputih dan yang ditangani melalui rumah-rumah singgah, yang bertujuan menampung dan mengedukasi anak jalanan yang dimiliki oleh pemerintah kota Surabaya adalah rumah singgah. Rumah singgah sendiri adalah bagian dari strategi dan kebijakan Dinas SosiaL Pemerintah Kota Surabaya dalam menangani anjal yang terdiri dari kebijakan preventif, pepresif, dan pemberdayaan (Setijaningrum, 2008).

Haryono (2012) mengidentifikasikan empat model kebijakan penanganan anak jalanan yaitu; (1) streetcentered intervention, kebijakan ini memfokuskan penanganan pada anak jalanan di tempat mereka hidup sehari-hari yaitu jalanan. (2) family-centered intervention, fokus penanganan model ini adalah memberdayakan keluarga untuk mencegah anak-anak menjadi hidup di jalan. (3) institutional-centered intervention, upaya model ini berpusat pada lembaga (panti), baik secara sementara (menyiapkan reunifikasi dengan keluarganya) maupun permanen (terutama jika anak jalanan sudah tidak memiliki orang tua atau kerabat). Pendekatan ini juga mencakup tempat berlindung sementara (rumah singgah), "Rumah Singgah" atau "open house" yang menyediakan fasilitas "panti dan asrama adaptasi" bagi anak jalanan. (4) community-centered intervention, model penanganan ini dipusatkan pada tingkat komunitas. Model ini termasuk pelaksanaan pengembangan komunitas (community development) dan penguatan kapasitas lembaga-lembaga sosial di masyarakat dengan penguatan jaringan sosial, pemerintah, maupun dunia usaha.

Dybicz (2005) menjelaskan bahwa selama ini program untuk menangani masalah anak jalan lebih banyak memfokuskan diri pada penguatan infrastruktur dan fasilitas fisik serta pembiayaan pendidikan anak jalan. Harapan dari program intervensi tersebut adalah menguatkan kapasitas anak jalanan untuk

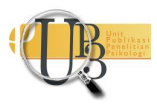


menjalani hidup. Kelemahan dari program-program intervensi tersebut, khususnya program rumah singgah adalah minim atau rendahnya kemampuan pelaksanaan lapangan yang dibutuhkan mencapai target program. Para pelaksana atau pendamping di rumah singgah adalah faktor kunci keberhasilan program. Rendahnya kemampuan para pelaksana program tersebut dalam menjalankan fungsi rumah singgah, tidak hanya menjadikan target program rumah singgah tidak tercapai tetapi juga menimbulkan persepsi negatif yang menjadikan rasa sejahtera anak-anak yang ditampung di rumah singgah.

Peran orangtua asuh juga tidak terbatas pada penyediaan kebutuhan dasar bagi anak, namun juga mampu mencari solusi atas permasalahan psikologis yang dialami anak-anak. Sebelum memahami permasalahan psikologis, orangtua asuh diharapkan mampu mendeteksi adanya masalah tersebut. Seperti yang kita ketahui, masalah yang dialami anak-anak jalanan yang ada di rumah singgah juga tidak hanya meliputi masalah sosial dan ekonomi, namun lebih jauh kondisi-kondisi tersebut juga berdampak terhadap kehidupan psikologis mereka. Penelitian yang telah dilakukan tahun 2015 pada 77 anak asuh dari 4 rumah singgah di Surabaya dan menggunakan Skala Kepuasan Hidup Anak merupakan adaptasi dari Multidimensional Students' Life Satisfaction Scale yang disusun oleh Huebner (2001), menunjukkan bahwa terdapat 12 anak dengan kepuasan hidup psikis yang sangat rendah (15.58\%), dalam kategori rendah 4 orang (5.19\%), kategori sedang 34 orang (44.15\%), dan kategori tinggi 27 orang (35.06\%) dan tidak ada sama sekali yang termasuk dalam kategori sangat tinggi. Artinya, masih ada anak yang memiliki kepuasan hidup secara psikis yang sangat rendah dan rendah yang kemungkinan disebabkan karena beberapa faktor di rumah singgah. Kondisi tersebut harus segera di tangani, karena anak yang memiliki kualitas psikis yang rendah di khawatirkan akan sulit untuk beradaptasi dengan tuntutan lingkungan yang semakin kompleks di kemudian hari. Jika tidak diatasi bukan tidak mungkin akan berpengaruh terhadap kehidupan anak-anak lain di rumah singgah. (Suryanto, dkk., 2015)

Selain itu penelitian tersebut juga mengungkap adanya fakta bahwa anak-anak di rumah singgah memiliki karakteristik psikologis yang rentan dan beresiko. Berdasarkan hasil wawancara dengan beberapa pembimbing/pengasuh di rumah singgah, didapatkan beberapa gambaran umum tentang karakteristik psikologis anak-anak yang berada di rumah singgah, sebagai berikut; (a) umumnya kondisi anak-anak masih terbawa dengan lingkungan sebelumnya, bicara masih kasar, masih sering bertengkar; (b) anak masih sulit di atur, kurang disiplin, tidak sopan; (c) suka melawan; (d) suka menceritakan masalah-masalah pribadi; (e) masih suka melakukan pelanggaran terhadap aturan yang ditetapkan yayasan/rumah singgah; (f) kecenderungan dendam jika mendapatkan hukuman fisik; (g) kecenderungan jadi pelaku dan korban perundungan/kekerasan; (h) karakter anak keras, susah di atur, karena kebanyakan dibesarkan oleh orangtua yang keras atau bahkan diterlantarkan (Suryanto, dkk, 2015).

Deteksi dini permasalahan psikologis pada anak asuh akan membantu orangtua asuh untuk menentukan langkah penanganan berikutnya. Hal ini sangat diperlukan agar masalah bisa selesai dan anak-anak dapat melanjutkan hidup dengan kondisi mental yang lebih sehat, adaptif dan produktif. Anak-anak dan remaja dengan kesehatan mental yang baik dapat mencapai dan mempertahankan fungsi psikologis, sosial dan kesejahteraan yang optimal. Mereka memiliki rasa identitas dan harga diri, keluarga dan hubungan kekerabatan, kemampuan untuk menjadi produktif dan belajar, kapasitas untuk mengatasi tantangan perkembangan dan menggunakan sumber daya budaya untuk memaksimalkan pertumbuhan. Selain itu, kesehatan mental yang baik dari anak-anak dan remaja sangat penting bagi partisipasi sosial dan ekonomi aktif mereka. Beban yang terkait dengan gangguan mental pada anakanak dan remaja cukup besar, dan itu dibuat lebih buruk oleh stigma dan diskriminasi. Dalam banyak situasi, gangguan mental yang kurang dapat dipahami, akan membuat mereka dipandang sebagai pembuat onar oleh lingkungan. Oleh sebab itu anak dan remaja yang mengalami permasalahan harus segera mendapatkan intervensi. 
Menurut Mental Health Foundation di Amerika (1999 dalam Dwivedi \& Harper, 2004), anak yang sehat secara mental mempunyai kemampuan untuk; (a) berkembang secara psikologis, emosional, kreatif, intelektual dan spiritual; (b) mengambil inisiatif, mengembangkan dan mempertahankan kelangsungan relasi personal yang memuaskan; (c) memanfaatkan kesendirian (solitude) dan menikmatinya; (e) menjadi sadar akan orang lain dan berempati dengan mereka; (f) bermain dan belajar; (g) mengembangkan rasa benar dan salah dan (h) menghadapi problem dan kemalangan serta belajar dari peristiwa-peristiwa ini, dalam cara-cara yang selaras dengan tingkat usia mereka.

\section{E T ODE}

\section{Prosedur penelitian}

Penelitian ini dilakukan dengan pendekatan kualitatif. Partisipan adalah pengasuh dari tiga rumah singgah anak jalanan yang ada di Surabaya. Jumlah partisipan dalam penelitian ini adalah 5 (lima) partisipan. Metode pengambilan data adalah dengan Focus Group Discussion (FGD). Fungsi utama dari pewawancara adalah untuk memfokuskan perhatian pada pengalaman yang diberikan dan dampaknya. FGD banyak digunakan dalam penelitian kualitatif yang dibatasi untuk situasi-situasi teretntu yang dialami partisipan. Kelompok ini terdiri darisejumlah kecil partisipan sehingga memungkinkan terjadi diskusi dari semua anggotanya (Stewart \& Shamdasani, 1990). Disini peran peneliti adalah fasilitator dan responden memiliki kebebasan untuk mengeksplorasi ide dan pikiran mereka sendiri.

Tabel 1. Identitas Partisipan Penelitian

\begin{tabular}{|c|c|c|c|c|c|c|c|}
\hline Nama & TTL & $\begin{array}{l}\text { Usia } \\
\text { (Thn) }\end{array}$ & Alamat & Pendidikan & Pekerjaan & Yayasan & $\begin{array}{c}\text { Lama } \\
\text { menjadi } \\
\text { pengasuh }\end{array}$ \\
\hline L.D & $\begin{array}{l}\text { Bandung, } \\
24 \text { April } \\
1978\end{array}$ & 38 & $\begin{array}{l}\text { Jl.Krembangan } \\
\text { Jaya Selatan }\end{array}$ & S1 Ekonomi & $\begin{array}{l}\text { Pembina } \\
\text { Anjal, } \\
\text { Marketing } \\
\text { Properti }\end{array}$ & $\begin{array}{l}\text { Rumah } \\
\text { Pintar } \\
\text { Matahari }\end{array}$ & 5 tahun \\
\hline W & $\begin{array}{l}\text { Jogjakarta, } \\
2 \text { Maret } \\
1967\end{array}$ & 49 & $\begin{array}{l}\text { Dupak } \\
\text { Bandarejo }\end{array}$ & SMU & $\begin{array}{l}\text { Swasta, } \\
\text { pengasuh }\end{array}$ & $\begin{array}{l}\text { Rumah } \\
\text { Pintar } \\
\text { Matahari }\end{array}$ & 4 tahun \\
\hline L.F & $\begin{array}{l}\text { Surabaya, } \\
22 \\
\text { Februari } \\
1996\end{array}$ & 20 & $\begin{array}{l}\text { Jl.Sidosermo } \\
\text { Puskesmas }\end{array}$ & Kuliah & $\begin{array}{l}\text { Relawan } \\
\text { Sanggar } \\
\text { Merah } \\
\text { Merdeka }\end{array}$ & $\begin{array}{l}\text { Sanggar } \\
\text { Merah } \\
\text { Merdeka }\end{array}$ & 1 tahun \\
\hline S.J & $\begin{array}{l}\text { Surabaya, } \\
8 \text { Agustus } \\
1968\end{array}$ & 48 & $\begin{array}{l}\text { Nginden Baru } \\
\text { Surabaya }\end{array}$ & SLTA & $\begin{array}{l}\text { Pengasuh } \\
\text { panti }\end{array}$ & Al Kahfi & 16 tahun \\
\hline $\mathrm{P}$ & $\begin{array}{l}\text { Kediri, } 21 \\
\text { Desember } \\
1977\end{array}$ & 39 & $\begin{array}{l}\text { Rusunawa, } \\
\text { Wonorejo }\end{array}$ & SMP & $\begin{array}{l}\text { Ibu rumah } \\
\text { tangga }\end{array}$ & Al Kahfi & 6 tahun \\
\hline
\end{tabular}

Adapun panduan FGD yang dibuat adalah meliputi beberapa pertanyaan yang diajukan sebagai upaya mendeteksi adanya gangguan masalah psikologis pada anak asuh, meliputi:

1. Hal-hal spesifik apa yang dapat teramati dari anak asuh anda?

INSAN Jurnal Psikologi dan Kesehatan Mental

2016, Vol. 1(2), 85-96

doi: 10.20473/JPKM.v1i22016.85-96 
2. Apakah anak asuh anda memperlihatkan perilaku bermasalah dan menyimpang? Jelaskan perilaku tersebut.

3. Bagaimana interaksi anda dengan anak asuh selama ini? Hambatan yang ditemui apa? Dampaknya bagi anak apa?

4. Problem emosional kerap ditemui pada anak-anak. Adakah problem tersebut pada anak asuh anda? Jelaskan bagaimana bentuk perilakunya?

5. Jelaskan faktor-faktor penyebab adanya masalah pada anak?

\section{HAS I L P E N E L I T I A N}

Berikut merupakan ringkasan dari hasil diskusi bersama orangtua asuh:

Tabel 2. Perilaku Spesifik Dari Anak Asuh

\begin{tabular}{|c|c|}
\hline Partisipan & Respon Partisipan \\
\hline P. & Kalau di rumah menurut \\
\hline S.J & Suka jahil/ mengganggu teman \\
\hline L.F & $\begin{array}{l}\text { 1. Kebiasaan anak yang meniru-niru gaya temannya } \\
\text { (malas, suka bermain tanpa mengenal waktu) } \\
\text { 2. Pernah memegang 'alat kelamin', untuk anak pria } \\
\text { ke wanita } \\
\text { 3. untuk anak-anak masih berkata kotor }\end{array}$ \\
\hline $\mathrm{L}$ & $\begin{array}{l}\text { 1. Tidak ada keinginan kuat } \\
\text { 2. Tidak mau mendengar, bilang ya tapi nanti tidak } \\
\text { dijalankan } \\
\text { 3. Suka memukul teman saat kumpul terganggu } \\
\text { 4. Mokong keras kepala } \\
\text { 5. Sulit baca tulis }\end{array}$ \\
\hline W & Memukul sesama teman \\
\hline
\end{tabular}

Perilaku spesifik yang diamati pada anak asuh meliputi kejahilan anak, suka mengganggu teman, malasmalasan, bermain tanpa mengenal waktu, memegang alat vital temannya, berkata-kata kotor, motivasi belajar yang rendah, membangkang, memukul teman, keras kepala, kesulitan belajar. Perilaku-perilaku yang diamati tersebut ada yang tergolong masih wajar khas anak-anak, namun juga ada perilaku yang haru menjadi pengawasan karena mengarah pada adanya problem psikologis seperti memegang alat kelamin teman dan melakukan pemukulan. Perilaku ini penting untuk dideteksi sejak awal agar anak asuh paham apa yang harus di perbaiki dari perilaku sehari-harinya.

Adz-Dzaky (2001) mengatakan bahwa deteksi dilakukan untuk mengenali gejala-gejala abnormalitas (ketidakwajaran) pada mental atau pada jiwa. Pendekatan diagnosis ini dilakukan untuk mencegah terjadinya kekalutan mental yang lebih parah yang dapat merusak kepribadian. Hal tersebut dapat membantu individu dalam mengembangkan cara berfikir, cara berperasaan, dan cara berperilaku yang baik dan benar, sehingga eksistensi seseorang bisa diterima dan diakui dalam lingkungan sosialnya sebagai sosok insan yang sehat secara sempurna. 
Tabel 3. Perilaku Bermasalah dan Menyimpang Anak Asuh

\begin{tabular}{ll}
\hline Partisipan & \multicolumn{1}{c}{ Respon Partisipan } \\
\hline P. & Tidak ada yang sampai menyimpang \\
S.J & $\begin{array}{l}\text { Suka mencolek-colek teman pada saat acara-acara } \\
\text { tertentu }\end{array}$ \\
L.F & $\begin{array}{l}\text { Untuk anak yang masih berusia SD yang telah } \\
\text { berbuat kesalahan, akan tetapi mereka masih } \\
\text { belum berani terbuka dan jujur }\end{array}$ \\
& $\begin{array}{l}\text { 1. Berbohong } \\
\text { L }\end{array}$ \\
& 3. Mau bunuh diri ancaman dengan pisau \\
& Perani menantang dengan pertanyaan saat \\
tidakuti
\end{tabular}

Secara umum perilaku anak-anak asuh di rumah singgah memang menunjukkan adanya masalah. Perilaku berbohong, susah di atur, suka mengganggu teman dan pengasuh menjadi perilaku yang muncul dalam keseharian mereka. Hal tersebut dinyatakan bukan perilaku menyimpang. Sementara itu kemunculan perilaku menyimpang dari anak asuh terdeteksi adanya anak yang mengancam bunuh diri dengan menggunakan pisau. Perilaku kecenderungan bunuh diri ini merupakan kondisi serius yang harus di cari akar permasalahannya.

Tabel 4. Hambatan Interaksi Dengan Anak Asuh

\begin{tabular}{ll}
\hline Partisipan & \multicolumn{1}{c}{ Respon Partisipan } \\
\hline P. & $\begin{array}{l}\text { Baik, hambatan yang ditemui selalu terkait dengan anak-anak yang } \\
\text { mengulangi apa yang di larang pengasuh, selalu menentang dan minta } \\
\text { dibebaskan melakukan apa yang anak-anak mau }\end{array}$ \\
& $\begin{array}{l}\text { Selalu dinasehati/ditegur, namun selalu terulang lagi perilaku yang } \\
\text { dilarang }\end{array}$ \\
L.F & $\begin{array}{l}\text { Pengalaman interaksi dengan kebiasaan anak-anak jalanan/ anak } \\
\text { dalam lingkungan keras. Hambatannya pengasuh harus mengajarkan } \\
\text { mulai dari hal-hal yang mendasar mengenai tata cara berperilaku yang } \\
\text { baik, mengajarkan anak-anak untuk bisa memahami apa hal positif } \\
\text { dalam dirinya itu memang susah dan butuh proses panjang. Dampak } \\
\text { bagi anak, sekarang anak telah mampu berjalan sesuai dengan yang } \\
\text { pengasuh dan lembaga ajarkan untuk hidup mereka yang sedikit lebih } \\
\text { baik }\end{array}$ \\
\hline
\end{tabular}




\begin{tabular}{ll}
\hline Partisipan & \multicolumn{1}{c}{ Respon Partisipan } \\
\hline L & $\begin{array}{l}\text { 1. } \begin{array}{l}\text { Intensif penanganan kepada anak asuh } \\
\text { 2. }\end{array} \\
\text { Dengan pendekatan menanyakan masalah anak dan } \\
\text { menyelesaikan dengan mengalihkan ke hal lain yang berkaitan } \\
\text { tapi tidak menyinggung masalah anak tersebut }\end{array}$ \\
W & $\begin{array}{l}\text { Harmonis. Hambatan yang sering dialami adalah masih ada orang tua } \\
\text { yang selalu mengekang anak-anaknya setelah di bimbing rumah } \\
\text { singgah. Dampaknya anak tereksploitasi }\end{array}$ \\
\hline
\end{tabular}

Adapun interaksi anak dengan orangtua asuh dan hambatan yang dialami oleh orang tua asuh selama ini adalah hubungan dapat dikatakan baik, intens bahkan beberapa pengasuh sudah mulai melakukan pendekatan personal untuk membantu anak mengatasi masalah. Kebanyakan orangtua asuh juga menyadari bahwa dalam memberikan pendampingan atau pembelajaran masih harus dilakukan berulang-ulang karena karakter anak asuh yang harus terus dikondisikan dan diingatkan untuk melakukan sesuatu. Hambatan lain yang ditemui terkait dengan orangtua kandung, dimana ada gap yang tidak bisa dihindari antara perlakuan terhadap anak di rumah singgah dengan perlakuan di rumah sendiri. Di rumahnya anak masih kerap mendapatkan tindakan kekerasan dari orangtua sehingga sulit bagi orangtua asuh untuk mengendalikannya.

Tabel 5. Permasalahan Emosional Anak Asuh

\begin{tabular}{|c|c|}
\hline Partisipan & Respon Partisipan \\
\hline P. & $\begin{array}{l}\text { Tidak pernah pamit kalau mau ke mana saja. Padahal } \\
\text { pengasuh sudah berkali-kali bilang kalau mau pergi ke mana } \\
\text { saja harus minta izin dulu. Perilaku selalu baik dan selalu } \\
\text { nurut kalau di rumah. }\end{array}$ \\
\hline S.J & $\begin{array}{l}\text { Ada anak yang dahulu yang selalu bersikap sopan dan santun } \\
\text { sekarang berubah menjadi cepat marah dan mudah } \\
\text { tersinggung }\end{array}$ \\
\hline L.F & $\begin{array}{l}\text { 1. Suka membentak anak bahkan pendamping } \\
\text { 2. Banyak anak yang kurang terbuka }\end{array}$ \\
\hline $\mathrm{L}$ & $\begin{array}{l}\text { 1. Cepat marah, main tanganbila ada temannya salah } \\
\text { dalam hal-hal sederhana atau mengupas masalah } \\
\text { dalam belajar atau hal lain } \\
\text { 2. Saling menjawab suatu masalah dengan emosi } \\
\text { 3. Masalah kecil diperbincangkan bisa menyulut amarah }\end{array}$ \\
\hline W & $\begin{array}{l}\text { Perilaku yang sering ditemui adalah seringnya menyelesaikan } \\
\text { masalah dengan saling memukul }\end{array}$ \\
\hline
\end{tabular}

Masalah utama dari anak-anak selalu didasarkan pada kehidupan emosional. Bentuk permasalahan emosional yang diungkapkan orang tua asuh meliputi anak yang mudah marah, mudah tersinggung, kurang terbuka, membentak orang teman dan pendamping, memukul teman, bicara dengan emosi yang memuncak. Emosi merupakan perasaan atau afeksi yang melibatkan suatu campuran antara gejolak 
fisiologis dan perilaku yang tampak. Pennebaker (1997) mengklasifikasikan afeksi positif yang mengacu pada derajat emosi yang positif, dari energy yang tinggi, antusiasme dan kegembiraan hingga perasaan sabar, tenang dan menarik diri. Afeksi negatif mengacu pada emosi yang sifatnya negatif, seperti kecemasan, kemarahan, perasaan bersalah dan kesedihan.

Tabel 6. Faktor Penyebab Anak Asuh Bermasalah

\begin{tabular}{ll} 
Partisipan & \multicolumn{1}{c}{ Respon Partisipan } \\
\hline P. & $\begin{array}{l}\text { Mungkin karena pergaulan di luar yang tidak dapat kita } \\
\text { kontrol, jadi membuat anak kalau di rumah menurut dan } \\
\text { bersikap baik dan kalau di luar anak merasa bebas tidak } \\
\text { terikat dengan aturan-aturan yang ada di rumah }\end{array}$ \\
S.J & Nilai di sekolah menurun \\
L.F & 1. $\begin{array}{l}\text { Kurang kasih sayang orang tua } \\
\text { 2. }\end{array}$ \\
L & 1. $\begin{array}{l}\text { Perang minat belajar anak } \\
\text { memukul kalau anak bersalah atau tidak nurut }\end{array}$ \\
& 2. $\begin{array}{l}\text { Membebaskan anak tanpa dibuat kedisiplinan dalam } \\
\text { pengasuhan } \\
\text { 3. }\end{array}$ \\
& $\begin{array}{l}\text { Tidak memberikan rasa kasih sayang dalam } \\
\text { mengasuh anak }\end{array}$ \\
1. & $\begin{array}{l}\text { Faktor belajar dari orang orang di sekitar anak } \\
\text { 2. Kurang harmonisnya hubungan orang tua } \\
\text { 3. }\end{array}$ \\
& Faktor kemiskinan
\end{tabular}

Sementara itu faktor penyebab yang membuat anak asuh bermasalah menurut orangtua asuh adalah faktor pergaulan, faktor lingkungan sekolah, kurangnya kasih sayang orangtua, kurangnya minat belajar pada anak, perilaku kekerasan yang diterima anak dari orangtua kandung, faktor kemiskinan dan keluarga yang tidak harmonis. Faktor-faktor tersebut tidak semuanya bisa dikontrol oleh orangtua asuh, sehingga dalam hal ini rumah singgah membutuhkan bantuan untuk dapat memberikan penanganan khususnya bagi keluarga kandung anak asuh.

\section{I S K U S I}

Mengingat begitu kompleks permasalahan yang mungkin timbul dalam kehidupan anak-anak di rumah singgah perlu kiranya tindak lanjut dari deteksi dini ini untuk lanjut pada penanganan. Hal tersebut sejalan dengan fungsi dari deteksi dini terhadap gangguan mental yang bermanfaat untuk mengembangkan nilai dan sikap secara menyeluruh serta perasaan sesuai dengan penerimaan diri (selfacceptance), membantu memahami tingkah laku manusia dan membantu manusia untuk memperoleh kepuasan pribadi, dan dalam penyesuaian diri secara maksimum terhadap masyarakat serta membantu individu untuk hidup seimbang dalam berbagai aspek, fisik, mental dan sosial. Disamping itu deteksi

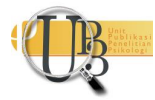


dini mempunyai fungsi dan tujuan, yaitu: fungsi pemahaman (understanding), fungsi pengendalian (control), fungsi peramalan (prediction), fungsi pengembangan (development), fungsi pencegahan (prevention), dan fungsi perawatan (treatment). Misal dengan melakukan deteksi dini terhadap gangguan mental seseorang akan terhindar dari hal-hal atau keadaan yang dapat membahayakan jiwa ataupun mental. Jadi deteksi dini adalah suatu upaya untuk mengenali kondisi kesehatan mental, terlebih gejala dan faktor atau pencetus yang bisa membuat kondisi mental menjadi tidak sehat (terganggu) secara dini.

Deteksi dini dapat dilakukan melalui pengamatan. Kehidupan sehari-hari dari anak merupakan gambaran nyata dari kondisi anak apa adanya. Hal-hal spesifik yang diamati pada anak asuh di rumah singgah meliputi kejahilan anak, suka mengganggu teman, malas-malasan, bermain tanpa mengenal waktu, memegang alat vital temannya, berkata-kata kotor, motivasi belajar yang rendah, membangkang, memukul teman, keras kepala, kesulitan belajar. Pada banyak literatur, memegang alat kelamin merupakan bentuk permainan dan eksplorasi seksual anak yang banyak terjadi pada anak-anak. Dikatakan masih dalam batas yang wajar ketika dilakukan secara spontan, terjadi dalam situasi bermain, terjadi antar anak-anak dengan usia dan besar tubuh yang sama, tidak ada tendensi apapun untuk menyakiti, tidak terencana, tidak berlanjut dan masih bisa teralihkan ketika pengawas mengatakan tidak boleh. Namun kondisi seperti ini tetap harus di awasi dan diberi pengertian bahwa hal tersebut merupakan perilaku yang tidak diharapkan.

Perilaku bermasalah dan menyimpang dari anak asuh terdeteksi adanya anak yang mengancam bunuh diri dengan menggunakan pisau. Percobaan bunuh diri merupakan salah satu gejala dari anak yang depresi. Faktor psikososial yang mempengaruhi depresi meliputi: peristiwa kehidupan dan stressor lingkungan, kepribadian, psikodinamika, kegagalan yang berulang, teori kognitif dan dukungan sosial (Kaplan, 2010). Depresi merupakan satu masa terganggunya fungsi manusia yang berkaitan dengan alam perasaan yang sedih dan gejala penyertanya, termasuk perubahan pada pola tidur dan nafsu makan, psikomotor, konsentrasi, anhedonia, kelelahan, rasa putus asa dan tidak berdaya, serta bunuh diri (Kaplan, 2010). Anak-anak di rumah singgah sedikit banyak mengalami banyak masalah dalam hidupnya. Kemiskinan merupakan faktor terbesar yang berkontribusi terhadap stress. Kemiskinan berkaitan dengan peristiwa-peristiwa berbahaya dan tidak terkendalikan dalam kehidupan anak-anak (Belle, 1990; Russo 1990).

Pengamatan juga dilakukan terhadap interaksi anak dan orangtua asuh. Interaksi anak dengan orangtua asuh selama ini dalam keadaan baik, intens bahkan beberapa pengasuh sudah mulai melakukan pendekatan personal untuk membantu anak mengatasi masalah. Kebanyakan orangtua asuh juga menyadari bahwa dalam memberikan pendampingan atau pembelajaran masih harus dilakukan berulang-ulang karena karakter anak asuh yang harus terus dikondisikan dan diingatkan untuk melakukan sesuatu. Hambatan lain yang ditemui terkait dengan orangtua kandung, dimana ada gap yang tidak bisa dihindari antara perlakuan terhadap anak di rumah singgah dengan perlakuan di rumah sendiri. Di rumahnya anak masih kerap mendapatkan tindakan kekerasan dari orangtua sehingga sulit bagi orangtua asuh untuk mengendalikannya terjadinya kekerasan di rumah dan dampaknya. Masingmasing anak akan bereaksi dengan cara yang sangat berbeda terhadap kekerasan yang mereka terima. Beberapa anak dilaporkan lebih agresif dan menjadi anti-sosial (Hughes, 1988; O'Keefe, 1995). Anak lain lain memiliki tingkat tinggi depresi, kecemasan dan gejala trauma (Sternberg, dkk., 1993; McCloskey, Figueredo \& Koss, 1995). Sebuah penelitian kualitatif di sebuah tempat perlindungan anak menemukan fakta bahwa anak-anak yang dipekerjakan oleh orangtuanya menunjukkan perilaku agresi (mengamuk, destruktif dan menyakiti anak-anak lain), dari tidak komunikatif (Den Haag, dkk. 1996, dalam Humphrey \& Mullander, 2016).

Sementara itu masalah utama dari anak-anak selalu didasarkan pada kehidupan emosional. Bentuk permasalahan emosional yang diungkapkan orang tua asuh meliputi anak yang mudah marah, mudah

INSAN Jurnal Psikologi dan Kesehatan Mental

2016, Vol. 1(2), 85-96

doi: 10.20473/JPKM.v1i22016.85-96

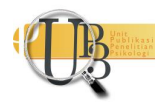


tersinggung, kurang terbuka, membentak orang teman dan pendamping, memukul teman, bicara dengan emosi yang memuncak menunjukkan bahwa anak asuh lebih banyak diliputi oleh afeksi negatif yang mengacu pada emosi yang sifatnya negatif, seperti kecemasan, kemarahan, perasaan bersalah dan kesedihan. Dapat dikatakan sebagian besar anak asuh memperlihatkan kecenderungan emosi yang temperamental. Temperamen didefinisikan sebagai perbedaan individu dalam bereaksi secara emosi, motorik dan reaktif terhadap stimulus yang diamati, yang muncul dalam pola perilaku regulasi diri dan atensi (Sanson, Hemphill \& Smart, 2004). Hal ini biasanya dianggap bersifat biologis yang relative stabil pada beberapa situasi yang dihadapi. Temperamen dapat dilihat dari tingkat reaktivitas, regulasi diri dan hambatan yang ada pada anak. Secara umum, temperamen mengacu pada apakah seorang anak bisa tenang, mudah marah, atau menjadi sulit diatasi. Temperamen juga terkait dengan kehidupan sosial anak, dimana regulasi diri yang tinggi dan reaktivitas yang rendah dikaitkan dengan pengembangan keterampilan sosial yang baik. Penelitian telah menyelidiki potensi interaksi antara temperamen anak dan gaya pengasuhan. Hal ini penting bagi orangtua untuk memahami kekuatan dan kelemahan alami anak mereka sehingga dapat mengadopsi strategi pengasuhan yang dapat menciptakan lingkungan kondusif bagi anak dengan temperamen tertentu (The Offord Centre of Child Studies, 2012 dalam Halton Early Years Mental Health Committee, 2014).

Faktor penyebab yang membuat anak asuh bermasalah menurut orangtua asuh adalah faktor pergaulan, faktor lingkungan sekolah, kurangnya kasih sayang orangtua, kurangnya minat belajar pada anak, perilaku kekerasan yang diterima anak dari orangtua kandung, faktor kemiskinan dan keluarga yang tidak harmonis. Anak-anak yang memperlihakan perilaku kekerasan dan destruktif, adalah anak-anak yang kurang ditanamkan perasaan secure dalam relasi dan interaksinya bersama keluarga. Banyak literature yang mengatakan pentingnya sosialisasi timbal balik dan attachment orangtua dengan anak. Sosialisasi timbal balik ialah pandangan bahwa sosialisasi adalah proses dua arah, anak-anak bersosialisasi dengan orangtua sama seperti orangtua bersosialisasi dengan anak. Keduanya terjadi secara harmonis. Sementara attachment mengacu pada suatu relasi antara dua orang yang memiliki perasaan yang kuat satu sama lain dengan melakukan banyak hal bersama untuk relasi yang berkelanjutan. Ada ikatan emosional di sana.

Attachment yang baik dan sangat emosional adalah secure attachment. Anak-anak yang di kemudian hari memperlihakan perilaku kekerasan dan destruktif, adalah anak-anak yang kurang ditanamkan perasaan secure dalam relasi dan interaksinya bersama keluarga. Secure attachment berkembang melalui pengasuhan yang konsisten, responsif, sensitif dan menghibur (Departemen Kesehatan dan Pelayanan Manusia Michigan, 2003). Seorang anak yang secure lebih percaya diri dan antusias dalam mengeksplorasi lingkungan mereka dan lebih kompeten dalam menguasai tantangan baru. Eksplorasi ini akan memberikan pengalaman yang penting bagi perkembangan anak. Hubungan attachment ini juga akan menetapkan pondasi untuk kemampuan seorang anak dalam memahami relasi, emosi dan moralitas (Klein, 2002 dalam Halton Early Years Mental Health Committee, 2014). Parenting yang tidak konsisten, menolak atau bermusuhan akan menempatkan anak pada risiko masalah sosial dan perkembangan emosional (Departemen Kesehatan dan Pelayanan Manusia Michigan, 2003).

\section{S I M P U L A N}

Deteksi dini masalah psikologis yang dilakukan pengasuh memberikan gambaran kondisi anak asuh memperlihatkan perilaku sehari-hari yang cenderung negatif. Bahkan seorang anak asuh di katakan memiliki usaha untuk bunuh diri. Sementara itu interaksi yang terjadi antara orangtua asuh dan anak asuh digambarkan sebagai relasi yang baik, hangat dan mendukung perkembangan anak asuh ke arah perilaku positif, meski harus dilakukan secara seksama, sabar dan proses pembelajaran yang harus diulang-ulang. Hambatan yang dialami orangtua asuh terutama ketika adanya perbedaan perlakuan

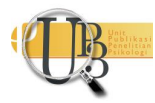


antara di rumah singgah dengan di rumahnya sendiri. Hal ini masih sulit untuk di kontrol, mengingat orangtua asuh belum banyak terlibat untuk melakukan intervensi pada keluarga. Problem emosional anak asuh yang masih sulit dikendalikan merupakan masalah tersendiri. Deteksi dini terhadap faktor penyebab masalah masih seputar keluarga inti anak asuh yang kurang supportif.

\section{PUSTAKA ACUAN}

Adz-Dzaky, M. (2001). Psikoterapi dan Konseling Islam; Penerapan Metode Sufistik. Yogyakarta: Fajar Pustaka Baru.

Belle, D. (1990). Poverty and women's mental health. American psychologist, 45(3), 385.

Departemen Kesehatan dan Pelayanan Manusia Michigan. (2003). Michigan.gov. Diakses tanggal 27 Oktober 2016 dari http://www.michigan.gov/mdhhs/0,5885,7-339-71550 2941 487165472--,00.html.

Direktorat Jenderal Rehabilitasi Sosial (2016). Anak Jalanan Rentan Eksploitasi. Diakses tanggal 27 Oktober 2016

dari https://rehsos.kemsos.go.id/modules.php?name=News\&file=article\&sid=1954.

Dwivedi, K. N. \& Harper, P. B. (2004). Promoting the emotional well-being of children and adolescent and preventing their mental-ill health. London: Jessica Kingsley.

Dybicz, P. (2005). Interventions for street children: An analysis of current best. International Social Work, 48(6), 763-771.

Halton Early Years Mental Health Committee. (2014). Social-emotional development in the early years: $A$ common message paper. Diunduh tanggal 28 Oktober dari http://www.ourkidsnetwork.ca/Public/Page/Files/73 Social\%20Emotional\%20Development \%2012.05.14.pdf.

Haryono, T. J. S. (2016). Perilaku Anak Jalanan dan Alternatif Model Pembinaannya. Diakses tanggal 28 Oktober 2016 dari http://trijokoantro-fisip.web.unair.ac.id/artikel detail-64206Antropologi\%20Perkotaan-PERILAKU\%20ANAK\%20JALANAN.html.

Huebner, S. (2001). Multidimensional students' life satisfaction scale. University of South Carolina, Department of Psychology, Columbia, SC, 29208.

Hughes, H. M. (1988). Psychological and behavioral correlates of family violence in child witnesses and victims. American Journal of Orthopsychiatry, 58(1), 77.

Humphreys, C. \& Mullender, A. (2016). Research in practice Children and Domestic Violence. Diunduh tanggal 28 Oktober 2016 dari http://www.icyrnet.net/UserFiles/mullender.pdf.

Kaplan, H. I., Saddock, B. J., Grebb, J. A. (2010). Sinopsis Psikiatri: Ilmu Pengetahuan Perilaku Psikiatri Klinis. Jakarta: Bina Rupa Aksara.

McCloskey, L. A., Figueredo, A. J., \& Koss, M. P. (1995). The effects of systemic family violence on children's mental health. Child development, 66(5), 1239-1261.

O'Keefe, M. (1995). Predictors of child abuse in maritally violent families. Journal of Interpersonal Violence, 10(1), 3-25.

Pennebaker, J. W. (1997). Writing about emotional experiences as a therapeutic process. Psychological science, $8(3), 162-166$.

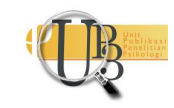


Russo, N. F. (1990). Overview: Forging research priorities for women's mental health. American Psychologist, 45(3), 368.

Sanson, A., Hemphill, S. A., \& Smart, D. (2004). Connections between temperament and social development: A review. Social Development, 13(1), 142-170.

Setijaningrum, E. (2008). Analisis kebijakan pemkot surabaya dalam menangani anak jalanan. Jurnal Penelitian Dinamika Sosial, 7, 16-22.

Suryanto, Herdiana, I. \& Chusairi, A. (2015). Pengembangan Model Parenting Skills Dalam Meningkatkan Kesejahteraan Psikologis (Subjective Well-Being) Anak Jalanan di Rumah Singgah (Penelitian tidak dipublikasikan). Fakultas Psikologi Universitas Airlangga, Surabaya.

Sternberg, K. J., Lamb, M. E., Greenbaum, C., Cicchetti, D., Dawud, S., Cortes, R. M., ... \& Lorey, F. (1993). Effects of domestic violence on children's behavior problems and depression. Developmental psychology, 29(1), 44.

Stewart, D. W., \& Shamdasani, P. N. (1990). Focus groups: Theory and practice (Vol. 20). Newbury: Sage publications. 